\title{
Mythmaking and Social Formation in the Study of Early Christianity
}

Ian Phillip Brown*

University of Toronto

\section{Abstract}

Burton Mack has made a number of important contributions to the study of early Christianity. One of, if not the most significant of these contributions is his use of the analytical categories of mythmaking and social formation in his construction of a social theory of religion. The analysis of mythmaking and social formation in early Christianity brings a critical historical and sociological focus to the study of Christian origins by focusing on the literary aspects of ancient texts, and the social aspects of ancient people and groups, and the dialectical relationship between the two categories. This article reviews the uses and criticisms of the categories of mythmaking and social formation in the study of early Christianity: beginning with Mack's work on a social theory of religion and his seminal study of the Gospel of Mark ( $A$ Myth of Innocence), and moving on to studies that have both taken up and critiqued Mack's use of the terms.

The project of understanding religion generally, and early Christianity specifically, in terms of the human practices of mythmaking and social formation is both a literary and sociological enterprise. It is literary in that it examines 'religious' texts as literary products with a literary history. It is sociological in that it aims to situate texts within particular socio-historical circumstances and examine how myths and the social groups who produce and use them influence and are influenced by each other. The categories of mythmaking and social formation have each made significant contributions to the study of religion, but in the social theory of mythmaking and social formation examined below, the two terms are greater than the sum of their parts. The all-important 'and' communicates the idea that mythmaking - the practice of producing stories - is dialectically related to social formation - the practice of organizing in groups based on modes of production. Stated generally, the study of mythmaking and social formation sets out to examine the relationship between group stories and a group's constitution. The theoretical utility of mythmaking in early Christianity has been well received by those who refuse to understand early Christianity as distinct from and incomparable to the world in which it emerged. The relationship between mythmaking and social formation, however, has been the site of more vigorous debate.

The categories of mythmaking and social formation are not new nor are they distinct to the study of early Christianity. The History of Religions School made popular the study of mythmaking and comparative myth in the late 19th century. In fact, comparative myth was, in this school, one of the primary approaches to the study of religion (Frazer 1993; Campbell \& Fairchild 1993; Lincoln 1991). The term 'social formation' originates in Marxist theory as a term that refers to the form a society takes as a result of a specific mode of production (Marx 1998, referred to in Mack 2000 , p. 282). And while both mythmaking on the one hand and social formation on the other have made important contributions to the study of religion in their own right, a theory of mythmaking and social formation brings these terms together in a distinct way.

In a very general sense, approaching the study of religion in terms of mythmaking and social formations leads to an analysis of how social groups and group stories relate to one another. An 
examination of social formation as a category in the study of religion can be found elsewhere (Redden 2015), so my task here is to focus on mythmaking and social formation in the study of early Christianity. To undertake this task, I will engage in some mythmaking of my own, starting with Mack's social theory of religion, then moving to his contributions to the study of early Christianity, namely his 1988 monograph A Myth of Innocence, the Society of Biblical Literature Seminar inspired by his work, and the various studies inspired by both.

\section{Burton Mack and a Social Theory of Religion}

In a series of essays and monographs (Mack 2000; Mack 2003; Mack 2008), Mack sets out to construct a social theory of religion that takes mythmaking and social formation as its major categories of analysis. His theory revolves around 'social interests' and their relation to mythmaking and social formation. 'Social interests' are defined generally as the concerns, needs, and desires of a unit of people. Mack relates social interests to mythmaking by arguing that social interests generate myths and mythmaking, and these myths are used to shape, criticize, think about, and argue over the ongoing maintenance of a society (Mack 2008, p. 81). Myths are differentiated from other forms of imaginative discourses because of the connection that mythmaking has to social interests and because both myths and social interests have a people in mind as a collective (Mack 2008, p. 121). That is to say, Mack differentiates myths from other imaginative fictions insofar as myths relate directly to a social need, whereas other imaginative fictions do not display such a clear association with the social collective. Mack's concept of mythmaking focuses on the productive and even constructive power of ideas. This arises from his reading of Louis Althusser on social formations (Mack 2000), which leads him to posit a theory of mythmaking and social formation wherein the relationship between the two is mutually constitutive. This theory is explicitly ideational in that it posits that ideas can exist in a (semi)autonomous state, giving them a relative independence from their social and material surroundings. Mack's reading of Althusser is as follows:

For Marx, the mode of most significance was economic or material production, and the now familiar theoretical model of a basic practice (base) resulting in a social formation (superstructure) was set for testing. The subsequent history of Marxist thought and political experience did not invalidate the base/superstructure model, but found that the three variable factors in the equation (practice, production and social formation) were in need of more detailed, conceptual specification. Althusser resignified the terms of the equation by working out a complex and sophisticated concept of society as a cluster of "semiautonomous instances," whereby "instance" refers to a pattern of practice that produces socially significant effects for the structure of and society and its on-going operations (Mack 2000, p. 283).

Mack uses Althusser's idea of 'semiautonomy' to break away from a more classical Marxist theory that sees social formations as dependent on and derived from the basic mode of production (Mack 2000, p. 284). This idea of 'semiautonomy' allows Mack to imagine a social theory where social location and practices of mythmaking are both independent variables and both have the ability to constitute social groups. ${ }^{1}$

Mythmaking and social formation are intimately tied in that they have a mutual effect on one another: mythmaking represents the intellectual labor 'invested in the enterprise of social formation, the way in which the process of social formation is rationalized, registered, and reproduced' (Mack 2000, p. 291). For Mack, myths function primarily in the maintenance of social formations. Mack's social theory of religion can be stated simply and in his own words: 'religion may be defined as a practice that produces myths and rituals of ideational consequence for the structure 
of a society as a whole' (Mack 2000, p. 292). Following this more general introduction to Mack's theory, it is now possible to examine how Mack applies this theory to early Jesus people and texts.

Burton Mack's A Myth of Innocence

In the preface to the 2006 reprint of the 1988 original, Mack states that his interests in $A$ Myth of Innocence were

in reimagining the social situations in which the various early views of Jesus and his teachings might be explained in terms of social interests and understood in terms of intellectual practices common at the time (Mack 2006, p. xi).

At the time of writing, the dominant event that shaped the ways in which scholars interpreted early Christianity was the 'Christ event', Jesus' death on the cross and subsequent resurrection. In Mack's view, the scholarly study of early Christianity could not advance because, by privileging the Christ event, it took over uncritically Christianity's own myth of origins (Mack 2006, p. 7). Furthermore, privileging the Christ event served to insulate early Christianity from critical sociological and historical studies given that, following Rudolph Bultmann (Bultmann 1951), the origins of Christianity were understood to be a unique event in history. The arrival of Jesus dramatically interrupted the course of human history and utterly and incomparably altered it. In claiming uniqueness for the Christ event, the origins of Christianity were effectively isolated from critical and comparative inquiry. ${ }^{2}$ Mack did not accept this understanding of Christian origins and posed two important questions:

What if the historical origins of the Jesus movement were not all that dramatic? What if the formation of the gospel were regarded as the origin of the Christian notion of dramatic origins? (Mack 2006, p. 9).

Mack refused to allow Christianity's account of its own origins to determine the explanation for its historical emergence. In order to counter the traditional view, Mack interpreted Christianity's story of its origins as myth: a myth with a particular socio-historical location, written by particular socio-historical actors, with particular socio-historical concerns.

Mack set out to reimagine Christian origins by placing a heretofore underrepresented emphasis on 'social experience as the occasion for imaginative activity and literary production' (Mack 2006, p. 15). Here 'social experiences' serve as the site for mythmaking and social formation: individuals or groups constitute themselves in relation to their social situations and reflect on those situations through 'imaginative activity and literary production'. In his understanding of 'social experiences' as the nexus of mythmaking and social formation, Mack is following Jonathan Z. Smith's constructive theory of religion, which claims that religious discourses are intimately related to the construction and maintenance of social structures and myths and rituals are the primary tools through which social structures are built and maintained (Mack 2006, pp. 20-23, especially footnotes 9 and 10 which draw heavily from Smith 1988). When a theory of mythmaking and social formation is turned loose on the Gospel of Mark (as in A Myth of Innocence), Mack is able to reimagine Mark as a text that illustrates the plurality ${ }^{3}$ of the social formations that made up early Christianity and the relationship between the social histories and the myths that emerged about Jesus (Mack 2006, p. 84).

After identifying the various mythic layers of Mark, Mack moves from myth to social formation and locates Mark's writing in a particular socio-historical moment: the destruction of Jerusalem and the Second Temple by the Romans in 70 CE (Mack 2006, p. 166). Scholars, for the most part, agree that the Gospel of Mark was composed shortly after the 
Jewish War and the destruction of Jerusalem and the Second Temple (Kloppenborg 2005; Arnal 2008b). The war not only destroyed Jerusalem and the Temple but also ravaged the Galilee and the Jewish cities that resisted the Romans, displacing or killing large segments of the population (Josephus, Jewish War, especially 3.110-339, 4.1-83). Mack argues that the situation post-War was one of incongruity (to borrow a term from J.Z. Smith) and that Mark's composers found themselves needing to explain their social situation and identity (or lack thereof ) in light of the disruptions of the Jewish War and the destruction of Jerusalem and the Second Temple. Given this very recent historical trauma, Mack argues the stories of the Jesus in the Gospel of Mark do not tell us about the historical Jesus, but rather, they represent an attempt by the author(s) of Mark to address present, post-war concerns. Mark, then, is

a gospel that presupposes the decisive events of Jesus' appearance, his violent end, the social history of the Jesus movement, the destruction of the temple, and the eventual manifestation of the glorious kingdom in power (Mack 2006, p. 171).

The stories in Mark are both fictional representations of the problems present in Mark's contemporary setting and the ideal solutions to those problems. The social formation from which Mark arose was experiencing an identity crisis following the Jewish War and the destruction of the Jerusalem Temple, and the Gospel of Mark served to rationalize, even mythologize, their marginalized social identity, '[t]he stories say, not only that they were right, but that they had been right all along, from the beginning' (Mack 2006, p. 203).

Mark's gospel created a myth of origins for a group in need of an identity. It stood at the intersection of many streams of cultural, literary, and social history. It was created by effort, intellectual effort, and it is marked by conscious authorial intention. Mark was a scholar. A reader of texts and a writer of texts (Mack 2006, p. 321).

Mack's analysis of Mark posits that Mark's myth of the execution of the innocent Son of God is directly related to the social situation experienced by the composers of Mark. Mack concluded that the Gospel of Mark represents an intellectual effort on the part of a people suffering from physical and social disruptions in the wake of the war. Mark is an experiment in mythmaking in the service of social formation, both of which result from the particular socio-historical situation post-Jewish war.

The importance of $A$ Myth of Innocence in the study of early Christianity should not be understated. The book led to a number of publications by Mack wherein he fleshed out a social theory of religion (reviewed above), as well as the formation of a Society of Biblical Literature Seminar that focused on reimagining early Christianity, especially in light of Mack's theories of mythmaking and social formation. Both of these contributions have been important in the study of religion generally and in the study of early Christianity specifically. In what follows, I will provide a review of how mythmaking and social formation in the study of early Christianity has been taken up after $A$ Myth of Innocence.

\section{After A Myth of Innocence}

A Myth of Innocence led to the rethinking of a number of taken for granted assumptions in the study of early Christianity and ultimately led to an ongoing Society of Biblical Literature Seminar: Redescribing Christian Origins (now Redescribing Early Christianity). The Seminar has published two books (Cameron \& Miller 2004b; Cameron \& Miller 2011) and is due for a third in the near future. The aim of the Seminar, as its name might suggest, was to redescribe various 
sites in early Christianity that have been plagued with unexamined assumptions and unresolved issues, such as the notion that Jesus was a reformer of Judaism, the notion of the first church in Jerusalem, the original impulse for the designation 'Christ', the attraction to the concept of Israel (all examined in Cameron \& Miller 2004), and Paul's exchange with the Corinthians (examined in Cameron \& Miller 2011). One of the driving forces behind the Seminar was an attempt to overcome the assumptions of older scholarship, and the adoption of Mack's categories of mythmaking and social formation was seen as an ideal means to this end. The Seminar examines ancient texts and people at what they describe as the juncture of mythmaking and social formation: a social location.

[A] social location is a discourse, constituted by a text (or set of texts) that both presupposes and takes up other discourses and that responds to social opportunities and cultural challenges in such a way that a significant intersection of social formation and mythmaking can be identified (Cameron \& Miller 2004a, p. 22).

Taken generally, the categories of mythmaking and social formation in the study of early Christianity refuse to allow source texts to dictate the terms of engagement. The texts most often associated with 'Christians' of the first and second century are not first and foremost unique religious texts but rather are products of particular socio-historical locations and actors who are involved in mythmaking in the service of a particular (and often local) social group. These 'myths' are understood functionally as imaginative stories that are produced by particular groups in particular times and places for particular reasons. This understanding serves to problematize any attempt to form a grand narrative of 'Christianity' and focuses instead on specific sites of mythmaking and social formation. In fact, the very idea of 'Christianity' as a phenomenon in the first century is a casualty of theories of mythmaking and social formation, given that a number different Jesus myths and social formations arose in the first and second century, many of which betray no genetic link to one another. The term 'Christian' does not appear until the late first or early second century (1 Peter 4:16), and even in its use here, it does not refer to a coherent and unified movement. So where 'Christianity' assumed a single Christ event which proliferated different but genetically related and dependent social groups, focusing on mythmaking and social formation as active processes reveals a number of different Jesus people and Jesus myths, genetically unrelated to one another. ${ }^{4}$

As mentioned above, the conjunction 'and' in mythmaking and social formation is a, if not the, key aspect of the social theory of religion based on mythmaking and social formation. The fact that mythmaking is almost always the first of the two terms reflects the fact that analyses of mythmaking and social formation, especially in the study of early Jesus people, tend to begin with the myth. This is so primarily because the vast majority of our data falls under the category of myth. The gospels are mythic, and while this does not mean we cannot make socio-historical claims on the basis of mythic texts, we need to be cautious about the claims we make. We should not, for example, assume that the myths present in our texts preserve a mirror image of the group that produced them (see Rollens 2011 for a concise exposition of the dangers of mirror readings of ancient Jesus myths). And while there is certainly a relationship between mythmaking and social formation, this relationship is not one-to-one. One of the key issues tackled by theorists who use mythmaking and social formation as analytic terms is just how this relationship is negotiated. This is especially the case for texts such as gospels, which give us very little direct information about their social situation, but it is also the case with text such as Paul's letters. And while Paul's letters (and here I refer only to the seven 'authentic' Pauline letters, 1 Thessalonians, 1 and 2 Corinthians, Galatians, Romans, Philippians, and Philemon) provide marginally more information regarding their social location, even here, Paul says surprisingly 
little about the people or groups he is addressing, and these letters too are replete with the mythmaking of Paul. Paul is far more interested in constructing a new identity for his addressees through, among other things, his Christ myth and his traditions of Israel (for example, 1 Cor. 15 and Galatians 4) than he is in reporting the makeup of the groups and individuals to whom he writes. Given the difficulty of sussing out a social formation from a particular Jesus text - gospel or letter-it is not surprising that when we attempt to examine ancient Christian texts in terms of mythmaking and social formation, the most frequent starting point is the myth.

The first step, then, is to recognize the mythmaking activities present in an ancient text. For example, let us take the Gospel of Mark. The content of the gospel does not report actual historical events; rather, it is a creative elaboration of one or more Jesus traditions, culminating in a distinctly Markan Jesus myth: the final gospel is a product of Mark's own intellectual labor (cf. Mack 2006, pp. 315-24; Arnal 2008, pp. 58-59). After recognizing and acknowledging that we are reading myths and not history as it happened, literary critical methods are very helpful in identifying themes within the myths. The identification and analysis of myths and mythmaking presume a particular intellectual motive force behind these ancient texts. Of course, this presumption is for the most part correct: the production of a text such as Mark is inarguably an intellectual process. But there are some (particularly William E. Arnal and Willi Braun who's objections are reviewed below) who are concerned that the focus on the intellectual aspect of mythmaking and social formation unduly privileges the former category and could potentially lead to a social theory that originates with ideas and not socio-economic conditions. Mack's understanding of mythmaking and social formation certainly allows ideas to have a constitutive force. This is evident in Mack's work on Mark, where he argues that Mark's Jesus myth brought people together based on the mutual recognition of the myth and that the myth constituted the gospel community (Mack 2006, pp. 319-321). This privileging of ideas is even more present in Mack's work on Q where he posits that the critical ideas present in Q led to a social formation more dependent on those critical ideas than the social situation from which they emerged (Mack 1993). Mack's ideational theory of mythmaking and social formation is grounded in his understanding of Althusser's 'semiautonomous' instances, which on Mack's reading understands that ideas are structurally related to but not necessarily dependent on a particular mode of production. This raises red flags for scholars who view social formation in a more classical Marxian sense, and it is at this point that an interesting disagreement emerges between proponents of mythmaking and social formation.

Objections raised by William E. Arnal and Willi Braun are the foundations upon which critiques of Mack's potentially ideational view of mythmaking and social formation are built (see especially Arnal \& Braun 2004). The problem with the idealist approach advanced by Mack is that it results in conceiving social or group belonging

in a relatively detached way, as though one can speak of social history only to the extent that a group self-consciously detaches itself from the sociocultural soup from which it "emerges" (Arnal 2004).

This led Arnal and Braun to compose a series of theses on social formation and mythmaking in an attempt to lend some theoretical stability to the categories. The theses are worth stating:

A Social Formation

$\mathrm{B}$ The social is not an interest but a basic fact of human being.

C Human interests are radically social.

D Morphologically divergent socialities may show themselves to be similarly motivated social formations in a shared totality.

E Relative to each other, early Christian groups are genetically independent. 
F Social formations are overlapping, convergent in some respects, divergent in others. They are never self-contained or pure.

G Mythmaking

$\mathrm{H}$ Ideas, including more or less elaborated myths, do not have motive force except that they are given motive force in specific and immediate context.

I Similarity of ideas, even when this similarity is the result of dispersal by some mechanism of transmission, is not automatically convertible to similarity or identity of motive force.

J Mythologoumena do not elaborate themselves organically out of their internal force, so finding first, second, or any sequential station stops on the way to elaborated myths is not necessary to get at the relationship between mythmaking and social formation.

$\mathrm{K}$ Myths and mythmaking are ultimately effects, not causes of socialities.

L Linearity need not be eschewed in historical hypotheses but should not refer to ideas, concepts, or rhetorical constructions exclusively and primarily.

M Ultimately, ideas do not require an idealist analysis.

$\mathrm{N}$ Conjunctions

O The 'and' in 'social formation and mythmaking' conveys a synchronic import.

$\mathrm{P}$ Mutual recognition is an effect rather than a cause of the proliferation of Christian groups (Arnal \& Braun 2004, pp. 462-467). ${ }^{5}$

As is evident from the theses, Arnal and Braun argue that material conditions are always the basis for mythmaking and social formation. They are not saying that the relationship between mythmaking and social formation is one directional but that any causative forces must be grounded in material conditions. Their reading of Althusser (in opposition to Mack's) grounds theories of mythmaking and social formation in the socio-economical (material) circumstances from which myths and social groups arise. On this view, Mack's notion of myths giving rise to social groups cannot work, given that the causative force behind the myths originated in a particular social situation (unarticulated by Mack). The emphasis on social location, however, should not be read as absolutely predictive. Similar, or even the same socio-economic conditions, will not necessarily produce similar ideas, but Arnal and Braun do assert that " in the final instance" they [ideas] are constrained by, shaped by, and refer to those conditions' (Arnal \& Braun 2004, p. 462). All this is to say that socio-economic conditions can and do give rise to social formation and mythmaking but only in that order: social formations, established and constrained by the particular material conditions of their place and time, produce myths. Arnal and Braun illustrate their point quite nicely with a hypothetical question:

Can we imagine that Jesus-group X or Christ group Y would have popped up on more or less similar motives and in more or less similar form without reference to "Jesus" or "Christ"? if the answer is yes, our point has been taken (Arnal \& Braun 2004, p. 463).

Mythmaking is indeed an intellectual activity whereby particular ideas are selected and elevated to a 'self-evidently authoritative status' (Arnal \& Braun 2004, p. 464), but these ideas do not have a motive force apart from the motive force given to them by their immediate context. Myths and mythmaking are effects, not causes of socialities. Ideas are certainly related to the material framework in which they operate, but ideas do not require an idealist analysis. And while the 'and' in social formation and mythmaking signals a synchronic relationship, Arnal and Braun argue that when it comes to questions of motive force, the base is always socioeconomic.

These criticisms, however, still leave plenty of room for mythmaking and social formation to be utilized helpfully in the study of early Christianity, but they do reign in some of the claims 
that one can make. For example, the focus on the generative power of the material base precludes the possibility of myths creating social formations. Examining the ways that myths and mythmaking work is still a useful practice and unraveling, for example, Mark's myth of an innocent executed is an important contribution, but explaining myths in terms of myths is not the end of an analysis that takes mythmaking and social formation seriously: one must ground the logic of the myth in a concrete social formation (Arnal 2011, p. 103). The grounding of myths in specific socio-economic milieus is helpful in theorizing how and why stories about Jesus were picked up and disseminated. On Arnal and Braun's hypothesis, Jesus was a useful lens through which to comment on particular socio-historical circumstances, but he was not the only lens. There were other social formations in the Graeco-Roman world that were experiencing similar socio-economic pressures as Jesus groups, but these pressures did not necessarily result in the composition, adoption, or circulation of myth about Jesus. Philosophical schools, mystery cults, and voluntary associations all operated in socioeconomic circumstances similar to Jesus groups and had their own myths. A comparative analysis of the mythmaking and social formation practices in these non-Jesus groups has facilitated extremely fruitful scholarship that examines early Jesus people alongside other social groups, especially voluntary associations, and increasingly philosophical schools. These comparisons are made possible, not by similar myths, but by similar social situations. This can be seen most clearly in recent work on voluntary associations and early Christian social formations (Kloppenborg \& Wilson 1996; Kloppenborg \& Ascough 2011; Ascough 2000; Ascough 2003; Harland 2003). These studies focus less on mythmaking and more on comparison and analogy of ancient Christian social formations with Graeco-Roman voluntary associations.

But while there has been an increase in the examination of social locations in ways that are less related to myths and mythmaking, there is still room and indeed need for a social theory of early Jesus people and texts that focuses on social formation and mythmaking. Arnal and Braun nicely illustrate the ways in which particular social situations give rise to mythmaking and social formation in Q, Thomas, and Paul (Arnal 2001; Arnal 1995; Arnal 2005; Arnal 2008a; Braun 1999). One of the greatest possibilities here is the exploration of the ways in which social locations and material factors affect not only just the motivations of gospel and letter writers but also the possibilities of mythic production. In the case of the Gospel of Mark, for example, we must imagine socio-historical actors with the compositional skills to write Mark and perhaps more significantly a social realm in which a text like Mark might fit. In terms of the former, compositional literacy was achieved by a select few and required significant leisure and economic and social capital. In terms of the latter, the circles in which relatively sophisticated textual products were read, circulated, and recognized as a cultural achievement were also small. Thus, the mythmaking in Mark is not only just situated in a post-war socio-historical situation but also in social circles where mythic production was materially possible and culturally significant. This relationship between myths and social formations maintains the primacy of social formations but extends the questions we should be asking of those social formations and integrates more formal aspects of mythmaking in a way that Mack's social theory did not.

\section{Conclusion}

One of the issues with reviewing the study of mythmaking and social formation in early Christianity is the fact that the terms do not make up a particular theoretical approach. Rather, they are analytical categories informed by, among other things, a Marxist, structuralist theory of society. Together, they have been put to use by Mack to construct a social theory of religion (Mack 2008), but, as I have argued above, the categories of mythmaking and social formation can do more than simply function within this particular social theory. 
Each offers insights into the study of religion generally and the study of early Christianity specifically. The productive aspect of mythmaking brings forth the intellectual and human elements of early Jesus texts, serves to ground the texts in everyday human practices, and posits a particular level of intellectual sophistication for those individuals. Analyzing early Christian mythmaking leads to an analysis of the social situations out of which the mythmaking arose and the positing of social formations that composed, disseminated, and consumed those myths. The 'and' in mythmaking and social formation should remind us that the two are related and interdependent and that a study of one should always include a study of the other. Our early Jesus texts are myths that were produced by and commented on particular social formations, both of which were situated in particular socio-economic situations.

\section{Short Biography}

Ian Phillip Brown received his BA from the University of Manitoba and his MA from the University of Regina and is currently a $\mathrm{PhD}$ candidate at the Department for the Study of Religion, University of Toronto. His dissertation examines early Jesus people and texts in light of Graeco-Roman intellectual culture, particularly as cultivated through ancient education and philosophical schools. His work focuses on 1 and 2 Corinthians and the Gospel of Thomas.

Notes

* Correspondence address: Ian Phillip Brown, Department for the Study of Religion, University of Toronto, 170 St. George St, Toronto, Ontario M5R2M8, Canada. E-mail: ianphillip.brown@mail.utoronto.ca

1 Mack's reading of Althusser has subsequently been criticized by William E. Arnal and Willi Braun.

2 For a critique of the discourse of the uniqueness of the Christ event, see (Smith 1990, pp. 39-41)

3 Mack posits a number of different Jesus social formations and Jesus myths behind Mark, including itinerants in Galilee, the congregation of Israel, a synagogue reform movement, and a Christ cult (Mack 2006, pp. 78-123)

4 The rise in the popularity of the term 'Jesus people' to refer to first and second century individuals and groups who composed and possessed texts and practices about Jesus can also be attributed to Mack and A Myth of Innocence.

5 This is a truncated presentation of Arnal and Braun's theses. The full version contains a paragraph of elaboration per thesis point and is well worth the read.

\section{Works Cited}

Arnal, W.E. (1995). The Rhetoric of Marginality: Apocalypticism, Gnosticism, and Sayings Gospels, HTR 88, pp. 471-494.

- (2001). Jesus and the Village Scribes: Galilean Conflicts and the Setting of Q. Minneapolis: Fortress Press.

- (2004). Why Q Failed: From Ideological Project to Group Formation. In: R. Cameron and M. P. Miller (eds.), Redescribing Christian Origins, pp. 67-87. Atlanta: Society of Biblical Literature.

- (2005). The Rhetoric of Social Construction: Language and Society in the Gospel of Thomas. In: W. Braun (ed.), Rhetoric and Reality in Early Christianities, pp. 27-48. Wilfrid Laurier: University Press.

—. (2008a). Doxa, Heresy, and Self-Construction: The Pauline Ekklessiai and the Boundaries of Urban Identities. In: E. Iricinschi and H. M. Zellentin (eds.), Heresy and Identity in Late Antiquity, pp. 50-101. Tübingen: Mohr Siebeck.

- (2008b). The Gospel of Mark as Reflection on Exile and Identity. In: W. Braun and R. T. McCutcheon (eds.), Introducing Religion: Essays in Honor of Jonathan Z. Smith, pp. 57-67. Oakville: Equinox Publishing.

- (2011). Bringing Paul and the Corinthians Together? A Rejoinder and Some Proposals on Redescription and Theory.

In: R. Cameron and M. P. Miller (eds.). Redescribing Paul and the Corinthians, pp. 75-104. Atlanta: Society of Biblical Literature.

Arnal, W.E. \& Braun, W. (2004). Social Formation and Mythmaking: Theses on Key Terms. In: R. Cameron and M. P. Miller (eds.), Redescribing Christian Origins, pp. 459-467. Atlanta: Society of Biblical Literature. 


\section{Ian Phillip Brown}

Ascough, R.S. (2000). The Thessalonian Christian Community as a Professional Voluntary Association, JBL, 119, pp. 311-328.

- (2003). Paul's Macedonian Associations: The Social Context of Philippians and 1 Thessalonians. Tübingen: Mohr Siebeck. Braun, W. (1999). Socio-Mythic Invention, Graeco-Roman Schools, and the Sayings Gospel Q, MTSR, 11, pp. $210-235$. Bultmann, R. (1951). Theology of the New Testament. Waco: Baylor University Press.

Cameron, R. \& Miller, M.P. (2004a). Introduction. In: R. Cameron and M. P. Miller (eds.), Redescribing Christian Origins, pp. 1-30. Atlanta: Society of Biblical Literature.

Cameron, R. \& Miller, M.P. (eds) (2004b). Redescribing Christian Origins. Atlanta: Society of Biblical Literature.

Cameron, R. \& Miller, M.P. (eds.) (2011). Redescribing Paul and the Corinthians. Atlanta: Society of Biblical Literature.

Campbell, J. \& Fairchild, J.E. (1993 [1972]). Myths to Live By Reprint edition. New York: Penguin Books.

Frazer, J.G. (1993 [1922]). Golden Bough: The Roots of Religion and Folklore Reprint edition. New York: Gramercy.

Harland, P.A. (2003). Associations, Synagogues, and Congregations: Claiming a Place in Ancient Mediterranean Society. Minneapolis: Fortress Press.

Kloppenborg, J.S. (2005). Evocatio Deorum and the Date of Mark, JBL, 124, pp. 419-450.

Kloppenborg, J.S. \& Ascough, R.S. (2011). Greco-Roman Associations: Texts, Translations, and Commentary : Attica, Central Greece, Macedonia, Thrace. Berlin; New York: Walter de Gruyter.

Kloppenborg, J.S. \& Wilson, S.G. (eds.) (1996). Voluntary Associations in the Graeco-Roman World. London: Routledge.

Lincoln, B. (1991). Death, War, and Sacrifice: Studies in Ideology \& Practice. Chicago: University of Chicago Press.

Mack, B.L. (1993). The Lost Gospel: The Book of Q and Christian Origins. San Francisco: Harper San Francisco.

. (2000). Social Formation. In: W. Braun and R. T. McCutcheon (eds.), Guide to the Study of Religion, pp. $283-296$.

London; New York: Cassell.

- (2003). The Christian Myth: Origins, Logic, and Legacy. New York; London: Continuum.

. (2006 [1988]). A Myth of Innocence: Mark and Christian Origins. Minneapolis: Fortress Press.

- (2008). Myth and the Christian Nation: A Social Theory of Religion. London; Oakville: Equinox.

Marx, K. (1998 [1932]). Introduction to the Critique of Political Economy. In: The German Ideology including Theses on Feuerbach and the Introduction to the Critique of Political Economy, pp. 1-23. Amherst: Prometheus Books.

Redden, J. (2015). Social Formation in the Study of Religion at Home and Abroad, Religion Compass, 9, pp. 501-511.

Rollens, S.E. (2011). Does Q Have Any Representative Potential? MTSR, 23, pp. 64-78.

Smith, J.Z. (1990). Drudgery Divine: On the Comparison of Early Christianities and the Religions of Late Antiquity. Chicago: University Of Chicago Press. 